\section{Przedmioty ekozagłady. Spekulatywna teoria hiperobiektów Timothy'ego Mortona i jej (możliwe) ślady w literaturze}

Anna Barcz

TEKSTY DRUGIE 2018, NR 2, S. 75-87

DOI: $10.18318 /$ td.2018.2.5

W tradycji europejskiej filozoficzne pytanie o przedmiot kieruje w stronę tego, co można poznać, podobnie pytanie o byt - co i jak istnieje. Języki nastawione na budowanie wiedzy o świecie - ontologia, semantyka czy epistemologia - a także o tym, co pozaświatowe metafizyka, ale i namysł nad językiem nieadekwatnym wobec przedmiotu poznania, wyznaczyły określone tory myślenia, z których wypada teoria, o której traktuje niniejszy artykuł. Bezsprzecznie ociera się ona o te kierunki dociekań, nawet konkretnie: o niemiecką filozofię transcendentalną (i pojęcie noumenów u Immanuela Kanta), o fenomenologię Edmunda Husserla (rzeczy jako fenomeny), o teologię apofatyczną (nieopisywalnego bytu absolutnego bez możliwości deskrypcji określonej) czy o różnicę ontologiczną Martina Heideggera. Umieściwszy się w takim horyzoncie poznawczym, musi jednocześnie zaprzeczyć wszystkiemu, co do tej pory zdawało się opisywać przedmioty realne, ponieważ nie jest teorią w znaczeniu oglądu czy wypracowywania filozoficznej koncepcji. Jest dramatem rozpoznania groźnych oddziaływań między tym, co istnieje, a przedmiotami zupełnie
NARODOWY PROGRAM ROZWOJU HUMANISTYKI

Artykuł powstał w ramach programu Ministra Nauki iSzkolnictwa Wyższego pod nazwą "Narodowy Program Rozwoju Humanistyki" w latach 2014-2019. Numer grantu: 0114/ $\mathrm{NPRH}_{3} / \mathrm{H}_{12} / 82 / 2014$.
Anna Barcz - dr, adiunkt, Katedra Anglistyki ATH w Bielsku-Białej; wykładowca Artes Liberales UW. Interesuje się ekokrytyką. Autorka książek: Realizm ekologiczny. Od ekokrytyki do zookrytyki w literaturze polskiej (2016); Animal Narratives and Culture: Vulnerable Realism (2017). Kierowniczka projektów naukowych poświęconych kulturowym studiom nad zwierzętami i literackim przedstawieniom groźnych zjawisk akwatycznych. Strona: https:// bielsko.academia. edu/AnnaBarcz. Kontakt: anna.barcz@ gmail.com 
nowego typu, walką języka filozoficznego z literackim, reakcją obronną i bezsilnością w czasie, który coraz to bardziej odsłania kolejne zjawiska wymierania planety, całej jej biosfery, a także kulturowe tego przyczyny i sposoby wyrażania. W dodatku nieosamotnionym, o czym świadczą kolejne ważne publikacje o zasięgu międzynarodowym: The Great Acceleration Johna Roberta McNeilla i Petera Engelkego', Elemental Ecocriticism. Thinking with Earth, Air, Water, and Fire ${ }^{2}$,Ecocriticism on the Edge. The Anthropocene as a Threshold Concept Timothy'ego Clarka ${ }^{3}$, Anthropocene Fictions. The Novel in a Time of Climate Change Adama Trexlera ${ }^{4}$, Dancing with Disaster Kate Rigby ${ }^{5}$, Risk Criticism Molly Wallace ${ }^{6}$ czy Facing Gaia Bruno Latoura ${ }^{7}$. Do nich należy również prezentowana tutaj pozycja: Hyperobjects. Philosophy and Ecology after the End of the World ${ }^{8}$ Timothy'ego Mortona, amerykańskiego filozofa i teoretyka współczesnej kultury. Dotyczy ona zarówno niepokojących diagnoz w postaci kryzysu ekologicznego, jak i estetyki. Hiperobiektowość to zatem także styl narracji, który cechuje rozczarowanie językiem nieprzystającym do doświadczenia niedających się pojąć, niesamowitych przedmiotów, twórcza niemoc wiedzy, która potrzebuje wzniosłości甲.

1 J.R. McNeill, P. Engelke The Great Acceleration. An Environmental History of the Anthropocene since 1945, Harvard University Press, Cambridge, MA-London 2014. Elemental ecocriticism. Thinking with Earth, Air, Water, and Fire, ed. by J.J. Cohen, L. Duckert, University of Minnesota Press, Minneapolis 2015.

3 T. Clark Ecocriticism on the Edge. The Anthropocene as a Threshold Concept, Bloomsbury Publishing, London 2015.

4 A. Trexler Anthropocene Fictions. The Novel in a Time of Climate Change, University of Virginia Press, Charlottesville 2015.

5 K. Rigby Dancing with Disaster. Environmental Histories, Narratives, and Ethics for Perilous Times, University of Virginia Press, Charlottesville-London 2015.

6 M. Wallace Risk Criticism. Precautionary Reading in an Age of Environmental Uncertainty, University of Michigan Press, Ann Arbor 2016.

7 B. Latour Facing Gaia. Eight Lectures on the New Climatic Regime, transl. C. Porter, Polity Press, Cambridge 2017.

8 T. Morton Hyperobjects. Philosophy and Ecology after the End of the World, University of Minnesota Press, Minneapolis-London 2013. Kolejne odniesienia umieszczam w tekście z numerem strony w nawiasach. Pierwszy rozdział książki zatytułowany Lepkość w moim przekładzie ukazuje się w niniejszym numerze "Tekstów Drugich".

9 Styl Mortona przywołuje więc takie temperamenty pisania literacko-filozoficznego jak Martin Heidegger, Aby Warburg czy Jacques Derrida, intensywne przeczesywanie języka w celu odnalezienia kulturowych przykładów i metafor dla tego, co niesamowite, niedyskursywne a realne, 
Książka Mortona, jak również te wymienione powyżej, świadczą o tym, jak bardzo zmienił się nurt ekokrytyki ${ }^{10}$. W latach 9o. ubiegłego wieku i na samym początku obecnego głównym problem była destrukcyjna dla środowiska przyrodniczego działalność człowieka, krytyka zastanych w kulturze relacji człowieka z przyrodą lub, szerzej - z naturą, opartych na dominacji gatunku ludzkiego, postulowanie zmian na rzecz zrównoważonego rozwoju i najogólniej ujmując - reformatorski zapał"11. Kluczowa była przebudowa uwarunkowanej kulturowo relacji z całym światem przyrody ożywionej i nieożywionej, natomiast ostatnie lata i teksty publikowane przede wszystkim po roku 2013 zajmują się głównie diagnostyką czasu nazywanego albo antropocenem, Epoką Człowieka, zmian klimatycznych, albo, jak woli Morton - globalnego ocieplenia, czasem niebezpiecznych zmian środowiskowych lub nawet końcem czasu $^{12}$. Wszystkie te określenia wskazują na antropogeniczny charakter przemian destrukcyjnych dla biosfery i na ich nieodwracalność. Kryzys ekologiczny stał się jednocześnie na tyle realny i przynależny doświadczeniu, że spowodował oryginalną reakcję wyobraźni, w studiach społecznych zaś przeniósł punkt ciężkości z dyskusji o zrównoważonej modernizacji na kwestie przystosowania się do groźnych zmian, częściej i intensywniej występujących katastrof i kataklizmów.

filozofię języka poezji, która wkracza w poznawcze szczeliny, jak w tytule wyboru wierszy Friedricha Hölderlina Co się ostaje, ustanawiają poeci: 100 najsłynniejszych wierszy (wyb. i przeł. A. Libera, słowo/obraz terytoria, Gdańsk 2003).

10 Już wcześniej próbowano, nawiązując do "fal" zaproponowanych przez Lawrence'a Buella w książce The Future of Environmental Criticism (2005), opisać zmiany w ekokrytyce, ale nie były one aż tak przełomowe, jak te po 2013 roku, ponieważ nie wpisywały się w diagnozę "nowej epoki", a raczej uzupełniały dotychczasowe studia o nowe konteksty (postkolonializm, gender i queer studies, animal studies czy problematykę klimatu) - por. S. Oppermann The Future of Ecocriticism: Present Currents, w: The Future of Ecocriticism: New Horizons, Cambridge Scholars Publishing, Newcastle upon Tyne 2011, s. 14-29.

Por. dyskusję i bibliografię zawartą w polskich omówieniach ekokrytyki angloamerykańskiej: J. Durczak Rozmowy z ziemiq̨. Tradycja przyrodopisarska w literaturze amerykańskiej, Wydawnictwo UMCS, Lublin 2010; J. Tabaszewska Zagrożenia czy możliwości? Ekokrytyka: rekonesans, "Teksty Drugie" 2011 nr 3, s. 205-220; A. Barcz Realizm ekologiczny. Od ekokrytyki do zookrytyki w literaturze polskiej, Wydawnictwo Naukowe "Śląsk", Katowice 2016.

Por. choćby: W. Steffen i inni The Anthropocene: conceptual and historical perspectives, „Philosophical Transactions of Royal Society" 2011 No. 369, s. 842-867; J. Zalasiewicz i inni When did the Anthropocene begin? A mid-twentieth century boundary level is stratigraphically optimal, "Quaternary International" 2014, s. 1-8; E. Kolbert Szóste wymieranie. Historia nienaturalna, przeł. T. i P. Grzegorzewscy, W.A.B., Warszawa 2014; I. Angus Facing the Anthropocene. Fossil Capitalism and the Crisis of the Earth System, Monthly Review Press, New York 2016. 
Już we wcześniejszych od Hyperobjects książkach, Ecology without Nature i The Ecological Thought, równie ważnych dla ekokrytyki, Morton unika, a wręcz manifestuje odrzucenie pojęcia natury na rzecz ekologicznego myślenia, które rozumie jako myślenie w szczelinach między kategoriami człowieka i natury i które jest na tyle powolne, by wprowadzić estetyzujący ogląd ${ }^{13}$. Natura niech dotyczy świata przyrody, świata oddalonego od ludzi, a myślenie ekologiczne ma dotyczyć nas - myślenia prawdziwie krytycznego ${ }^{14}$.

Hyperobjects ukazują się w 2013 roku i pokazują przełom w nurcie ekokrytyki. To nie ludzie mają wpływ na środowisko przyrodnicze, ale pewne nowe przedmioty na ludzi i całą biosferę, dlatego czas ten nazywa się „wiekiem asymetrii". Jak rozumieć te nowe przedmioty? Nie starać się zrozumieć, ale przyjrzeć się temu, jak Morton je myśli, jakiego rodzaju przykłady podaje na ich oddziaływanie na ludzi i środowisko przyrodnicze, jak je opisuje, by uchwycić coś, co nazywa nastrojeniem (attunement) na nie. Nie są to bowiem przedmioty w zasięgu ludzkiej skali czasu i przestrzeni; mimo że mogą być odpadami ludzkiej działalności, to są nieznanymi i niedającymi się badać obiektami - termin ten dodatkowo podkreśla ich obcy charakter; są także hiper, co znaczy, że znajdują się ponad i poza naszym poznaniem; teoretycznie są transcendentne i myląco nietranscendentalne, ale są: „tutaj, w tej oto przestrzeni społecznej i empirycznej" (27).

We wstępie dowiadujemy się, czym mogłyby być hiperobiekty, gdyby chcieć je nazwać: złożami ropy i materiałów radioaktywnych, samym uranem lub plutonem, machiną kapitalizmu albo zwykłym przedmiotem obdarzonym „długim trwaniem", jak foliowa torebka (1). Są one bowiem obiektami spekulatywnymi, nieposiadającymi desygnatów, ale ustalone przez Mortona własności, do których należą: najbardziej syntetyczna - lepkość, potem nietutejszość (nonlocality), nieregularne falowanie (temporal undulation) i fazowość (phasing).

Lepkość oznacza, że hiperobiekty przyklejają się do wszystkiego, co jest $\mathrm{z}$ nimi w pewien sposób związane. Ma to znaczenie dla doświadczania ich bliskości jako czegoś radykalnie wyobcowującego z poczucia bezpieczeństwa w przestrzeni publicznej, w domu i we własnym ciele: „Wszystkie są na mnie. Są mną. Czuję się jak Neo w Matrixie, który w przerażającym zachwycie

13 T. Morton Ecology without Nature. Rethinking Environmental Aesthetics, Harvard University Press, Cambridge, MA 2007, s. 7, 12. 
podnosi do twarzy rękę pokrytą lustrzaną substancją rozpływającej się klamki, podczas gdy jego wirtualne ciało zaczyna się rozpadać" (28). Powodują paranoję, gdy zmieniają formułę twierdzeń o nich na to, co już spowodowały, wówczas Morton przeskakuje na stronę bierną i pisze: ,jestem do nich przyklejony". Lepkość hiperobiektów wiąże się także ze świadomością odmiennej percepcji i hiperobiektowych składników doświadczenia estetycznego. Wiele mówiącym tego przykładem jest fragment, w którym Morton niezwykle osobliwie, ekspresyjnie i osobiście opisuje, co odbiera z muzyki rockowego zespołu My Bloody Valentine (29-30) i jak. Nazywa ją ", prawdziwie ekologiczną", ponieważ pozwala ona znaleźć się w wyjątkowej przestrzeni wypełnionej trudno uchwytywanymi dźwiękami, w której delikatny i efemeryczny kobiecy wokal zagłuszany jest ostrością elektrycznych gitar. Lepkość tej muzyki, jej usidlający charakter, wzniosłość i towarzyszące Mortonowi poczucie przerażenia - wszystko to jest projekcją rozciągającą w czasie ten moment, kiedy Odyseusz przywiązany do masztu wystawia się na śmiercionośny śpiew syren. Porównanie to działa na wyobraźnię i jest charakterystycznym sposobem Mortona na zwrócenie uwagi czytelnika na grozę przynależną światu, w którym istnieją przyklejone i niesłychanie trudne do wykrycia hiperobiekty. Potężne doświadczenie estetyczne okazuje się językiem pośredniczącym w obcowaniu z nimi.

Nietutejszość hiperobiektów odsłania bezmiar ich niebezpieczeństwa. Przede wszystkim są niewidoczne gołym okiem, dokładnie jak radioaktywne promieniowanie czy zmiany chemiczne w atmosferze, które intensyfikują spalanie się słońca. Są niewyczuwalne, jak toksyny znajdujące się w tym, co spożywamy (38), i dlatego tak łatwo można zaprzeczyć ich istnieniu. Podobnie gdy aktywizują się w sposób nieprzewidywalny i tymczasowy, poza ludzkimi skalami czasowości (58) - na tym polega ich przejściowa aktywność. Nieskończoność form, które przybierają, i wielość powiązań między przedmiotami, które wykorzystują, powoduje zmienność ich faz: zajmują wielowymiarową przestrzeń fazową, która uniemożliwia ich całościowe zaobserwowanie (70).

Morton nie formułuje twierdzeń o hiperobiektach, ponieważ nie można ich zatrzymać umysłem (58). Z ich opisu wynika jednak, że są realne i absolutnie nieludzkie, a także że przejawiają się w świecie. Ontologia zorientowana na rzeczy spotyka się tutaj z perspektywą fenomenologiczną, formuje język i przygotowuje na poznanie tych gigantów wielkości i małości. W takich momentach rozpada się dyskursywny język Mortona, najczęściej w pierwszej części książki stawiającej pytanie o to, czym są hiperobiekty. Morton próbuje 
wyjaśnić ich istnienie, posiłkując się wiedzą zaawansowanej fizyki teoretycznej, przede wszystkim fizyką kwantową i teorią względności, ale i wiedzą na temat najpoważniejszych katastrof i zagrożeń ekologicznych. To mu jednak nie wystarcza. Musi, jak Odyseusz, ale i fenomenolog, dokonać ekspozycji samego siebie na te niewyobrażalnie niebezpieczne obiekty, które nie mogą stać się przedmiotami poznania, dlatego odsłania własne treści myślenia, jak gdyby pod wpływem oddziałującego na niego hiperobiektu. Wówczas zmienia się prowadzona przez niego narracja, tak jak w przełożonym rozdziale poświęconym lepkości, w którym widać, jak hiperobiekty oblepiają pamięć, zanieczyszczają język, zniekształcają doświadczenie rzeczywistości, ponieważ nie mogą być zrozumiałe, ponieważ poprzedzają myślenie, ale nie warunkują go. Objawiają się w chaotycznym sposobie pisania, który należy traktować nie jako chaotyczność stanu umysłu autora, ale jako próbę rozpisania dramaturgii doświadczania realności hiperobiektu, oddania poczucia zagubienia - czasem nawet przerażenia - i uciekania w wielość narracji zapośredniczonej licznymi przykładami z filmu, muzyki, sztuki czy literatury. Te kulturowe języki intensywnie uczestniczą w procesie pisania. Są częścią przyjętej przez Mortona perspektywy fenomenologicznej i takiego sposobu opisywania doświadczenia, który wypełnia je treścią, a także uzewnętrznia jego przekaz w postaci strukturalnych i emocjonalnych zniekształceń formy, jaką jest dyskurs filozoficzny. Dramat tak często wypowiadany wprost przez Mortona polega więc na tym, że doświadczenie to nie może być w pełni opisane, ponieważ hiperobiekt wymyka się przedmiotowi poznania, i dlatego jest obcym, zanieczyszczającym język obiektem. Świadczą o tym intensywne doznania w ciele i w umyśle, które przypominają zaburzenia afektywne, nie w sensie jednostki chorobowej, ale stanu świadomości, która wykrywa, że nawet jej najbardziej subiektywna rzeczywistość rozpada się w niepojętym procesie samounicestwienia. Według Mortona żyjemy już w czasie „po końcu świata", w którym przyszłość stała się przeszłością i za szybko nadeszła (19). „Ludzie wkroczyli w epokę hipokryzji, bezsilności i słabości”, czego wyrazem jest „estetyczne poczucie (feel) asymetrii pomiędzy nieskończoną władzą poznania a nieograniczonym istnieniem bytów" (22). To, co można poznać, a to co istnieje, uległo rozszczepieniu jak śmiercionośny atom.

Do hiperobiektów opisywanych przez Mortona pasuje metafora materiałów radioaktywnych. Ich siła rażenia, niemożność ich usunięcia czy utylizacji, niewyobrażalna skala niebezpieczeństwa i zniszczenia jest porażająca, zarówno poznawczo, jak i estetycznie. W przypadku opisu nuklearnego testu Trinity i katastrofy platformy wiertniczej BP Deepwater Horizon Morton 
zamieszcza ich zdjęcia - wizualne figury „końca świata” $(8,33)$. Służą mu one za metaforyczne podpowiedzi w myśleniu hiperobiektów, podobnie jak wiele reprodukowanych w książce prac artystycznych. Hiperobiekty wyzywają wyobraźnię do walki o sposób i adekwatność ich wyrażenia. Kontekst zagłady, a właściwie - ekozagłady, powoduje, że wraca pytanie o język, w jego najbardziej poznawczo-odsłaniającej formie. Podobnie jak dla Paula Celana takim językiem wypowiadanym z konieczności odniesienia do Zagłady Żydów jest język poezji, tak dla Mortona to intensywne poszukiwanie semantycznych skrawków w różnych językach tekstów kultury, ale i danych dostarczanych przez naukę, by wbrew nieuchwytności poznawczej hiperobiektów nie przestawać o nich myśleć w kontekście postępującej ekozagłady ${ }^{15}$.

Hiperobiekty przypominają o estetycznym wpływie katastrofy na narrację, czego dobitnym przykładem jest „czarnobylski katastrofizm”, dokładnie omówiony w krakowskim tomie fragmentów literackich, artykułów naukowych i rozmów Po Czarnobylu. Stanowi on przykład takiego nurtu literackiego, który nie od razu, a po wielu latach od tragedii 1986 roku, wytworzył „polifonię" języków, narracji i gatunków pisania o Czarnobylu. Tragedia ta, nieraz opisywana jako tragedia ludzi, zwierząt i środowiska przyrodniczego, uchyliła hierarchizujący dyskurs o gatunkach, ale i zwróciła uwagę państw spoza bloku wschodniego na wyjątkowo poważne ekologiczne konsekwencje intensywnie prowadzonej przez ZSRR modernizacji w czasie wyścigu zbrojeń. Dla Ukraińców okazała się katalizatorem dążeń niepodległościowych ${ }^{16}$, a dla Zachodu - figurą zagrożenia ekologicznego ze strony Europy Wschodniej, która, o dziwo, długo nie mogła przedostać się do anglojęzycznej ekokrytyki w charakterze tekstu kultury.

Koncepcja Mortona pozwala spojrzeć na hiperobiekty jako na narracje odsłaniające w literaturze poczarnobylskiej toksyczne ślady po katastrofie. Przejawiają się one za pośrednictwem skażonego języka albo inaczej - lepkość tej katastrofy zabiera środki wyrazu lub zmienia je nie do poznania. Pomocne jest to, że w literaturze katastrofa czarnobylska przetwarzana w prywatnym, indywidualnym doświadczeniu pisarskim przynosi oryginalną

15 O pamięci Hiroszimy i Zagłady, jak mogą się one przenikać w literaturze, podobnie jak apokaliptyczne opowieści o klimacie i Zagładzie, interesująco pisała ostatnio Marta Tomczok w artykule: Cień Zagłady i grzyb Hiroszimy. Wokół powieści Paula Austera "W kraju rzeczy ostatnich", w: Po Czarnobylu. Miejsce katastrofy w dyskursie współczesnej humanistyki, red. I. Boruszkowska, K. Glinianowicz, A. Grzemska, P. Krupa, Wydawnictwo UJ, Kraków 2017, s. 291-299.

16 O. Zabużko Planeta Piołun - Dowżenko - Tarkowski - Von Trier albo dyskurs nowej grozy, w: Po Czarnobylu..., przeł. K. Kotyńska, s. 49-50. 
refleksję nad językiem. Takim przykładem intymnego języka doświadczenia katastrofy jest książka NRD-owskiej pisarki Christy Wolf - Störfall (Wypadek $)^{17}$, która powstała najwcześniej spośród innych literackich odniesień do Czarnobyla, bo w roku 1987. Mimo to rzadko jest omawiana (nie pojawia się w tomie Po Czarnobylu $)^{18}$.

Narratorka Wypadku to kobieta dojrzała, która w dniu, gdy w radiu poinformowano o wybuchu reaktora w Czarnobylu, oczekuje na wiadomości ze szpitala, ponieważ jej brat przechodzi operację wycięcia nowotworu. Koincydencja tych zdarzeń przenika do języka wewnętrznego monologu skierowanego najczęściej do brata, a także zmienia język i znaczenie otoczenia (bohaterka pracuje w tym dniu w swoim ogrodzie). Dzień ten staje się dziwnie wyjątkowy, zdominowany przez kolejne informacje z radia i brak wiadomości o bracie. W przeciwieństwie jednak do choroby brata, której terminologię opanowała i potrafi się nią posługiwać, nie zna podstawowych kryteriów ryzyka nuklearnego ${ }^{19}$. Mimo mierzalnego promieniowania, radioaktywności nie widać ani nie czuć, w dodatku niezauważenie pojawiają się w narracji bohaterki nowe określenia czasu "przed” i „po" katastrofie. Początkowo irytujące zalecenia (niespożywania owoców i warzyw czy mleka), które zdawałoby się bohaterka lekceważy, a nawet się z nimi przekomarza, powodują, że nagle zdaje sobie sprawę, że istnieją jacyś „oni”, którzy „odebrali apetyt na sałatę i szpinak". Chce o nich spytać, ale wychodzi jej krótkie, zamykające sprawę stwierdzenie: „Kto, oni”20. Słyszy, jak naukowcy zaprzeczają sobie, są wściekli i bezsilni, zaraz potem stwierdza: ,a teraz wszystko to opadało na nas razem z deszczem przenoszącym radioaktywne substancje”21. „To" odnosi się do czegoś więcej niż do radioaktywnego opadu - do nieodwracalnych zmian w języku, które z neutralnych nazw rzeczy czynią je na zawsze sklejone z wybuchem atomowym. Przykładowo „biała chmura” nie może oznaczać już czystości czy niewinności w poezji: „Teraz, myślałam, obierając ugotowane ziemniaki, ciekawiłoby mnie sprawdzić, który pierwszy z poetów śmiałby

17 Korzystam z nieco późniejszego wydania angielskiego: Ch. Wolf Accident. A Day's News, transl. H. Schwarzbauer, R. Takvorian, The University of Chicago Press, Chicago 1989. The Environmental Imagination of the Global, Oxford University Press, Oxford-New York 2008, S. 182-191.

Tamże, s. 184 . 
wychwalać białą chmurę. Niewidoczna chmura zupełnie innej natury zyskała uwagę naszych uczuć - całkowicie innych uczuć. I, myślałam dalej z czarnym humorem, że to wykopało białą chmurę z poezji na zawsze"22. Język ulega tu niepokojącej dysproporcji, staje się nieadekwatny do opisu takiego zagrożenia jak Czarnobyl, przestaje być "tutejszy” z powodu „tych najcholerniejszych obiektów" ${ }^{23}$, które nawet w słowie „wypadek" będą już odtąd z nim zlepione.

Reportażystka, która w 2015 roku otrzymała za swoją twórczość Nagrodę Nobla, zdołała chyba najmocniej, jak dotąd, oddać piekło Czarnobyla - ustami ocalałych świadków katastrofy. Czarnobylska modlitwa ${ }^{24}$ Swietłany Aleksijewicz powstała w 1997 roku i doczekała się wielu znakomitych omówień, które można znaleźć także w tomie Po Czarnobylu. Tamara Hundorowa w artykule Gatunek czarnobylski: wyparcie realnego i nuklearna sublimacja stwierdza, że Aleksijewicz swoim reportażem uczyniła Czarnobyl „miejscem tego, co traumatyczne, «niewyrażalne» w kulturze, podobnie jak i inne fundamentalne wydarzenia XX stulecia: Auschwitz, Hiroszima czy Holokaust"25. Szczególnie „nieprzedstawialność", niemożność wyrażenia przez świadków tego, co zaszło w Czarnobylu - tak jak i Wolf podkreślają oni niewidzialność radioaktywności - w książce Aleksijewicz rozpisanej na ich głosy zapoczątkowuje „czarnobylski katastrofizm” (termin ukuty przez Hundorową) będący, jak argumentuje badaczka, „potężnym modelem estetycznym”26. Nabiera on dramatyzmu przez to, że katastrofa była początkowo niezauważalna, bezwonna i bez smaku, a skala rażenia tak nieprawdopodobna, gdy odkryto jej skutki, że ludziom urywał się język ${ }^{27}$.

22 Tamże, s. 55. Por. także U. Heise Sense of Place..., s. 185.

23 Tamże, s. 60.

24 S. Aleksijewicz Czarnobylska modlitwa. Kronika przyszłości, przeł. J. Czech, Czarne, Wołowiec 2012.

T. Hundorowa Gatunek czarnobylski: wyparcie realnego i nuklearna sublimacja, przeł. P. Tomanek, w: Po Czarnobylu, s. 56.

Tamże, s. 61.

Podobnie w dwóch filmach dokumentalnych wyprodukowanych przez TVN Turbo: Czarnobyl. Wstęp wzbroniony (2015) i Powrót do Czarnobyla (2017) w reżyserii A. Kurasza, które miały w zamyśle odmitologizować to miejsce, żyjący świadkowie (w filmach - głównie pracownicy elektrowni) opowiadają o awarii reaktora w sposób szczególnie dramatyczny, przerywany znaczącym milczeniem. Ważną rolę w obu dokumentach odgrywa poruszająca muzyka, która wypełnia wyludnione przestrzenie zony filmowane z dronu. Występujący w nich 
Jedna z rozmówczyń Aleksijewicz podkreśla, że „tego się nie da opowiedzieć! Nie da się opisać! Nawet przeżyć... To wszystko jest takie moje..." ${ }^{28}$. Język świadectwa załamuje się, w sposób widoczny przybywa trzykropek, wykrzykników, nawiasów, jak gdyby reportażystka chciała uwzględnić wszystkie pauzy, krzyki i emocje pokrzywdzonych. Krzywda jest w tym przypadku nie do ogarnięcia i wymaga tych zlepionych z nią znaków interpunkcyjnych, które same z siebie nic nie znaczą, ale one też świadczą o hiperobiektywności Czarnobyla. O milczeniu świadków, które Aleksijewicz uwzględniła w zapisie tekstowym, tak pisze Andrea Zink: „Milczenie osób, z którymi przeprowadzane są wywiady, ich samotność i pauzy poświadczają fundamentalne rozdarcie w świecie rzeczy, ponieważ są oznaką nicości"29. Dodajmy - nicości w przerażającej sytuacji o niewidocznych skutkach ontologicznych nie tylko dla ludzi, ale i całej przyrody. Aleksijewicz uzupełnia narrację o katastrofie o świadectwa odstrzeliwania i zabijania czarnobylskich zwierząt, wycinania i zakopywania pociętych drzew. Tak zwane „dezaktywacyjne" działania usuwały nuklearne odpady, zarówno te ludzkie, jak i przyrodnicze. Katastrofę czarnobylską można określić jako ekozagładę nie dlatego, że przyroda nie zdołała się odrodzić w miejscach wysiedlenia ludzi, ale ponieważ została ona na zawsze sklejona z tym przedziwnym radioaktywnym hiperobiektem, który wciąż tam promieniuje i przypomina o wydarzeniu, które przewróciło do góry nogami świat ludzi, zwierząt i otaczającej je przyrody, zabierając im na zawsze przyszłość.

Czarnobyl to jeden z wielu przykładów, którymi posługuje się Morton w swoim myśleniu hiperobiektów. Dzięki narracjom zdającym sprawę z wyjątkowości i niewyobrażalnej skali takiego hiperobiektowego niebezpieczeństwa, jakim była choćby nieprzewidywalnie przemieszczająca się chmura radioaktywna, a także dzięki tropieniu śladów zanieczyszczenia języka, hiperobiekty nie są już hipostazami, ale stają się niesamowicie realne. Ich obecność tematyzują także inne narracje, które nie odwołują się bezpośrednio do Czarnobyla, tylko do pewnego modelu katastrofy, dzięki

dziennikarz Jacek Podemski, nastawiony na demaskację czarnobylskich mitów, wchodzi w miejsca, w których promieniowanie niespodziewanie rośnie i z których musi błyskawicznie uciekać. Tylko dzięki licznikowi Geigera jest w stanie rozpoznać groźne przejawy czarnobylskiego hiperobiektu.

A. Zink Na skraju pustki - Czarnobyl w tekstach i obrazach, przeł. J. Bilmin-Odrowąż, w: Po Czarnobylu, s. 73 [kursywa. - A.B.] 
czemu można wyodrębnić literaturę katastrofy atomowej ${ }^{30}$. Takim tekstem jest powieść Ściana Marlen Haushofer, po raz pierwszy wydana w 1963 roku. Pisana na początku lat 6o., w okresie narastającego lęku spowodowanego wyścigiem zbrojeń, przedstawia niesamowite i oryginalne wyobrażenie katastrofy nuklearnej.

Na początku książki czytamy: „w tym czasie rozmawiano stale o wojnie atomowej i jej skutkach"31. Rozmawiano, lecz nikt nie był poinformowany, na czym polega ryzyko nuklearne. Bohaterka, samotna i dojrzała kobieta, musi więc poradzić sobie w sytuacji nieznanej zupełnie katastrofy - pojawienia się przezroczystej, szklanej ściany, która odgrodziła ją od reszty świata, gdy spędzała kilka dni w domu swoich przyjaciół, położonym w lesie. Ten niezwykły obiekt, który nagle jak gdyby „wyrósł” albo "opadł” w przyrodniczym otoczeniu, został przez przypadek odkryty przez psa. Mimo wyostrzonego zmysłu węchu i doskonałej orientacji przestrzennej - to pies myśliwski - wpada on na ścianę i boleśnie się rani (13). Przeszkoda przypomina ścianę, jest „zimna” i „gładka” jak szyba okienna, na którą także wpada kobieta, ale nie jest żadną ścianą ani szybą: „Myślałam, że zwodzą mnie zmysły, ale wiedziałam oczywiście, że to nieprawda. Pogodziłabym się raczej z lekkim obłąkaniem niż z tym niewidzialnym strasznym przedmiotem" (14). Niewidzialny, ale realny; niepojęty i straszny, ale materialny hiperobiekt podważa poczucie istnienia, wytrąca z rzeczywistości: „To po prostu nie mogła być prawda, takie rzeczy się nie zdarzają, a jeśli się zdarzają, to nie w małej wiosce w górach, nie w Austrii i nie w Europie” (17). Zarazem domaga się określenia: „przyzwyczaiłam się nazywać tę tajemniczą rzecz ścianą, przecież musiałam dać temu jakąś nazwę, skoro już istniało" (15) ${ }^{32}$.

Ściana przedstawiona jest w powieści Haushofer jako przerażający hiperobiekt, dla którego kobieta nie znajduje wyjaśnienia. Reprezentuje zupełnie nieznany rodzaj niebezpieczeństwa, przed którym nie da się ochronić: „Dotąd jednak każde niebezpieczeństwo groziło ze strony człowieka, nie mogłam więc tak szybko się przestawić" (21). Stanowi przeszkodę umieszczoną

30 Wyobrażenie katastrofy atomowej w myśl koncepcji hiperobiektów Mortona może dotyczyć różnych tekstów przed Czarnobylem, np. rosyjskiej fantastyki naukowej z początku XX wieku opisującej ekozagładę (V. Briusow, I. Ehrenburg, V. Nikolski).

31 M. Haushofer Ściana, przeł. Z. Kania, PIW, Warszawa 1990, s. 9 [kursywa - A.B.] Kolejne cytaty umieszczam $w$ tekście z numerem strony w nawiasach.

32 Ściany nie widać także w filmie o tym samym tytule będącym ekranizacją powieści - por. Ściana, reż. J. Pölsler, Arthaus 2012. 
w przestrzeni, ale i przeszkodę dla myśli. Nie wyjawia tego, co się zdarzyło, ale sygnalizuje, np. wtedy gdy radio, które nie było popsute, brzęczy „tak obco i nieludzko" (24). Za ścianą rozciąga się niepokojący widok, jakby świat stanął w miejscu, a ludzie i zwierzęta zostali uśpieni: „Jeśli to była śmierć, to przychodziła szybko i łagodnie, niemal w sposób pełen miłości" (27). Niepojęta realność ściany, której pojawienie się odizolowało kobietę w przyrodniczym otoczeniu, w towarzystwie kilkorga zwierząt, stanowi porażającą metaforę zagłady świata, który został za szybą.

Do samego końca powieści nie wiadomo, co i dlaczego zostaje odgrodzone, gdzie się zaczyna, a gdzie kończy ściana. Dlaczego jest ona przezroczysta? Ocalała kobieta znajduje się przecież żywa w dolinie otoczonej przyroda, oddalonej od miasta, cywilizacji, przemysłu i gospodarstw rolnych, od wszystkiego, gdzie rozegrało się coś strasznego, coś jak niewidzialna radioaktywność, zabiło życie wkoło, pozostawiając martwe figurki ludzi i zwierząt. Ściana jako literacki koncept zachęca do traktowania jej metaforycznie. Jest także oknem w powieści, przez które widać, co się stało ze światem podczas niewyjaśnionej ekozagłady. Porównywana do Robinsona bohaterka Haushofer musi przeżyć, znajdując się w rzeczywistości po końcu świata, ale musi też pisać, „żeby nie postradać zmysłów”. Hiperobiekt ściany nie zostanie zdemaskowany, ponieważ narrację tę charakteryzuje poznawcza asymetria między tym, co się zdarzyło, a tym co się zdarza (szczególnie na końcu książki), tak jak w koncepcji Mortona.

Z jednej strony Morton myśli hiperobiekty za pomocą teorii spekulatywnej. Przypisuje istnienie obiektom nierzeczywistym (nie z tej rzeczywistości) i hipostazuje je w sposób niemal absolutny, twierdząc, „czym one nie są". Z drugiej - sam doświadcza rozpadu języka, którym miał rozpracować hiperobiekty. Wielokrotnie zauważa, że hiperobiekty są przerażające, nawet te oddalone od człowieka w przestrzeni kosmicznej, zarazem zależy mu na projekcji doświadczenia końca tego (jego) świata z hiperobiektowej perspektywy. Chce urealnić problemy, wydawałoby się nierozstrzygalne, które stały się pustymi stwierdzeniami, jak ocieplający się klimat, zagłada gatunków, niedające się ukryć toksyczne odpady nuklearne. Do tego potrzebuje mocnej hipotezy przemawiającej za oddziaływaniem hiperobiektów. Takie hipotezy formułowane są w języku fizyki i astronomii teoretycznej, ale Mortonowi chodzi o jeszcze jedno rozumienie hiperobiektu, ukryte pod powierzchnią wstydu, to, które wiąże koniec świata z antropocenem (7) i o którym traktuje literatura katastrofy atomowej - literatura ekozagłady. Chodzi o związek hiperobiektów z człowiekiem, którego sam myśli, gdy wsiada do samochodu czy 
zapala światło. Jest jego wcieleniem i doskonale wie, że obudził się za późno ze swojego snu - antropo-snu, a teraz, dopiero po przebudzeniu doświadcza niemocy. Wciąż jednak może w nieuzasadniony sposób użyć przemocy, nawet w świecie panujących hiperobiektów, ponieważ sam jest niebezpiecznym narzędziem ekozagłady. Przypomina o tym niezidentyfikowany mężczyzna na końcu powieści Haushofer, który mimo wszechobecnej śmierci za szybą z zimną krwią zabija zwierzęta siekierą. To jedna z najbardziej obcych postaci w literaturze, z którą pozostawia nas autorka - postać o mylącej sylwetce człowieka.

\section{Abstract}

\section{Anna Barcz}

UNIVERSITY OF BIELSKO-BIALA

The Objects of the Ecocide: Timothy Morton's Speculative Theory of Hyperobjects and Its (Possible) Traces in Literature

Barcz begins by discussing the main concept behind the title of Timothy Morton's book Hyperobjects (2013). Hyperobjects are a new type of objects characterized not only by the ecological crisis caused directly by humans, but also dangerous environmental and climatic phenomena that seem beyond our comprehension. The theory of hyperobjects relates to the issues most recently at stake in ecocriticism. These issues allow us to identify a distinct trend within the field - ecocriticism in the age of asymmetry (a phrase coined by Morton). In the second part, Barcz refers to the concept of hyperobjects as a possible narrative in the literature dealing with atomic disasters - a type of ecocide found in the works of Marlen Haushofer, Christa Wolf or Svetlana Alexievich.

\section{Keywords}

hyperobjects, ecocide, nuclear disaster, ecocriticism, age of asymmetry 